\title{
PODEŽELJE V SODOBNIH RAZVOJNIH RAZMERAH
}

Kako potrebno, a strokovno izjemno zahtevno in odgovorno je načrtovati, usmerjati in spremljati razvoj podeželja, je ponovno dokazal mednarodni znanstveni kongres »Podeželje v sodobnih razvojnih razmerah « (Rural Areas in the Modern Development Conditions). Tovrstno delo pa pridobi še dodatno vrednost, ker vključuje območja, ki so (bila) izpostavljena velikim demografskim spremembam, gospodarski krizi, političnim pritiskom ali/in celo vojaškim spopadom. Na Ohridu (od 30. marca do 2. aprila 2006) je 60 referatov kolegov iz devetih držav (Makedonija, Hrvaška, Srbija, Črna gora, Bosna in Hercegovina, Slovenija, Madžarska, Bolgarija, Romunija) tehtno in poglobljeno predstavilo težišča sodobne problematike podeželja .

Zanimivoje, da so kljub razlikam v naravno- in družbenogeografskih potezah (priznati pa moramo, da tudi navkljub nekaterim zelo podobnim izhodiščem) nekateri strukturni problemi podeželja praktično »doma« povsod: depopulacija, odseljevanje mladih, šibka gospodarska moč podeželja, »odmiranje« storitvenih dejavnosti, pomanjkljiva infrastruktura v najširšem pomenu. V teoretsko-metodološkem pogledu še vedno ostajajo dileme in nerazrešena vprašanja glede kriterijev in meril za opredelitev in tipologijo podeželskih območij. Podobna (sicer prilagojena vsakokratnim posebnostim) so tudi izhodišča glede razvoja podeželja $\mathrm{v}$ prihajajočih desetletjih. Skupna je ugotovitev, da so najbolj uspešni prijemi, katerih pobude prihajajo neposredno od lokalnega prebivalstva.

Za ilustracijo podajamo nekaj izbranih dejstev, ki bodo pomagala nekoliko osvetliti raznolikost podeželskih struktur v posameznih državah. V večini omenjenih držav podeželje zajema okrog $90 \%$ ozemlja, na podeželju živi 30 - 50\% prebivalstva posamezne države, sooča se z demografskim deficitom in osiromašeno izobrazbeno strukturo.

- V Makedoniji je 29 naselij opredeljenih kot mestnih, 1750 pa kot podeželskih.

Industrija je večino podeželja zaobšla, soočajo se z visoko stopnjo brezposelnosti.

Ceste so večinoma netlakovane, električna mreža ni ustrezna. Večino vrtcev, šol,

zdravstvenih postaj, kulturnih institucij in trgovin so zaprli.

- V Srbiji je na podeželju vsako peto gospodinjstvo enočlansko, polovica je dvočlanskih; na podeželju živi 100.000 neporočenih moških. Veliko ljudi, ki imajo prijavljeno stalno prebivališče v Srbiji, dejansko živi v tujini. Produktivnost kmetijstva je nizka, mehanizacija stara, kmetijstvo je neprilagojeno tržnim razmeram. Podeželska infrastruktura je nerazvita, zemljiško-posestni odnosi nosijo težko breme polpretekle zgodovine in sedanjosti.

- $\quad$ Na Madžarskem je kmetijska kriza vplivala na povečanje brezposelnosti, javne službe na podeželju usihajo. Poseben problem predstavlja velik delež romskega prebivalstva.

- $\quad$ Kako usmerjati razvoj podeželja na Hrvaškem, saj se je samo iz Like v zadnjih tridesetih letih izselila tretjina prebivalstva, in kjer je očiten primanjkljaj pozitivne vloge regionalnega središča? In to uskladiti z Istro, tradicionalnim pokazateljem prihodnjih procesov, ki tudi beleži prebivalstveno rast le v obalnem pasu (10 naselij od 640), zaledje pa se je izpraznilo. 
- Podeželje v Sloveniji se sooča z demografsko osiromašenostjo in socialnoekonomsko šibkostjo. Znotraj te splošne slike pa se povsod pojavljajo posamezna demografsko zdrava naselja oziroma družine, zelo občutljive na širše socialne razmere. Med ključne razvojne probleme nedvomno sodijo: demografski in okoljski problemi, zemljiškoposestna razdrobljenost, prepuščenost prebivalstva lastni »nemoči«, razkrajanje vaške skupnosti in neusklajeno delovanje razvojnih dejavnikov.

Kljub vsem problemom pa vzpodbudno delujejo primeri dobrih praks. Selo Koštunići v Srbiji je pilotni projekt, v katerega je bilo v zadnjih nekaj letih vloženih veliko sredstev, ustanovljenih 8 podjetij, povezanih s pridelavo in predelavo kmetijskih proizvodov na tradicionalen način. Pridelki (krompir, slive, maline, živina itd.) so našli tržišče na ameriškem in EU trgu. Istra je že v fazi nadgradnje turizma na podeželju. Spodbudne so dosedanje madžarske izkušnje (bodo takšne tudi slovenske?) s programom Leader, ki izpostavlja prostorski in integralni pristop, lokalne pobude, partnerstva in lokalne akcijske skupine, inovacije, mreženje in sodelovanje, lokalno financiranje in upravljanje. Prostorsko zelo opazno je razraščanje obrtno-trgovskih-poslovnih con na lokacijsko zanimivih delih slovenskega podeželja.

Eden glavnih namenov kongresa je bil z izmenjavo izkušenj tudi posredovati državi gostiteljici napotke in priporočila, kako naj se loti zapletene problematike razvoja podeželja. Tako so bili sklepi konference (v obliki deklaracije) posredovani tudi makedonskim državnim oblastem in upa(j)mo, da ne bodo samo romali v predal. Zlasti je bila izpostavljena vloga geografije in vključevanje geografskega raziskovanja pri pripravi temeljnih državnih razvojnih dokumentov (tj. Nacionalne strategije razvoja podeželja).

Tovrstnega znanstvenega srečanja, ki naj bi se v prihodnje odvijalo vsako drugo leto, so se iz Slovenije udeležili trije predstavniki. Avtorici zapisa sta predstavili nove razvojne priložnosti za podeželje v Sloveniji. Že tradicionalno dobro sodelovanje z Univerzo v Skopju izpred desetletij je na ta način dobilo nov impulz (izmenjava strokovnih izkušenj, študijski obiski, interes za skupno terensko delo). 